\title{
Fungsi Ruang Terbuka Hijau (RTH) di Kecamatan Biringkanaya Kota Makassar
}

\author{
Nurul Latifah Busrah ${ }^{1}$, Jan Robert ${ }^{1}$, Mithen Lululangi ${ }^{1}$ \\ ${ }^{1}$ Pendidikan Teknik Sipil dan Perencanaan Fakultas Teknik Universitas Negeri Makassar \\ Email: *nurullatifahbusrah@gmail.com
}

(c) 2018 - UEJ Program Studi Pendidikan Kependudukan dan Lingkungan Hidup Universitas Negeri Makassar. Ini adalah artikel dengan akses terbuka dibawah Licensi CC BY-NC-4.0 (http:/creativecommons.org/licenses/by-nc/4.0)

\begin{abstract}
.
This research is a quantitative descriptive study, which aims to determine the function of green open space in the Biringkanaya District of Makassar City. The research object is 3 RTH in Biringkanaya District. Data collection uses documentation techniques, interviews, observation, and surveys. The descriptive analysis showed that the average function of RTH in Taman Ayam Daya is 50\%, which means the category is, Untia Mangrove Forest and Baddoka Golf Course is $77.78 \%$ which means good category. So the results of this study show that the Untia Mangrove Forest and Baddoka Golf Course have the highest percentage which means fulfilling functions among other green open spaces.
\end{abstract}

Keywords: Green Open Space, Mangrove Forests, Urban

\section{PENDAHULUAN}

Pengertian ruang terbuka hijau (RTH) adalah bagian dari ruang-ruang terbuka (open space) yang diisi oleh tumbuhan, tanaman dan vegetasi (endemik maupun introduksi) guna mendukung manfaat ekologis, sosial-budaya, dan arsitektural yang dapat memberikan manfaat ekonomi (kesejahteraan) bagi masyarakat (Sembel et al, 2015).

Ruang terbuka hijau adalah suatu lahan terbuka tanpa bangunan yang mempunyai ukuran, bentuk, dan batas geografis tertentu dengan status penguasaan apapun, yang didalamnya terdapat tetumbuhan hijau berkayu dan tahunan (perennial woody plants), dengan pepohonan sebagai tumbuhan penciri utama dan tumbuhan lainnya (perdu, semak, rerumputan, dan tumbuhan penutup tanah lainnya) sebagai tumbuhan pelengkap, serta benda-benda lainnya sebagai pelengkap dan penunjang fungsi RTH tersebut.

Kota Makassar adalah salah satu kota besar di Indonesia dan termasuk sebagai kota metropolis dengan jumlah penduduk yang mencapai 1.769 .920 juta penduduk dengan luas wilayah sebesar 175,77 km2 (BPS, 2017). Kota Makassar menjadi salah satu kota yang perkembangannya cukup pesat dalam beberapa tahun terakhir ini dan salah satu kota di Indonesia dengan tingkat pembangunan kawasan ekonomi dan kawasan pemukiman sangat cepat (Rasyid dkk. 2017). Pemerintaah Kota Makassar sendiri kesulitan memenuhi target RTH yang diamanatkan Peraturan Menteri dalam Negeri tentang Ruang Terbuka Hijau Kawasan Perkotaan.

Besarnya manfaat yang diberikan oleh RTH juga menjadi pertimbangan mengapa RTH sangat penting dalam sebuah kota. Maka pemerintah kota Makassar perlu melakukan perencanaan pembangunan RTH dan meningkatkan fungsi RTH yang sudah ada di Kota Makassar. Hamid Shirvani (1985:7) memasukkan open space sebagai salah satu dari delapan elemen arsitektur kota. Ruang terbuka merupakan elemen penting dalam pembentukkan arsitektur kota. Ruang terbuka (open space) 
dapat diartikan sebagai lansekap, hardscape (jalan, trotoar dan sejenisnya), taman dan area rekreasi didaerah perkotaan.

Ruang terbuka hijau dapat diklasifikasikan berdasarkan berbagai hal, antara lain berdasarkan kepemilikan, fisik, pola pembentukan atau struktur ruang, serta fungsi. Fungsi RTH meliputi fungsi pelayanan fasilitas umum (fasum) bagi masyarakat untuk melakukan kegiatan-kegiatan aktif di dalamnya, seperti berinteraksi/berekreasi, berolahraga, berwisata hutan, dan lain-lain, fungsi pengaman, peneduh, dan keindahan kota secara proporsional pada ruang-ruang kota, dan fungsi budidaya pertanian bagi kegiatan pertanian kota.

Perkembangan perkotaan seharusnya seirama dengan kebutuhan dan pertumbuhannya pun harus direncanakan secara tepat demi tetap tercapainya kenyamanan hidup dalam lingkungan yang sehat, misalnya terbentuknya keseimbangan antara ruang terbangun dan RTH secara proporsional, baik di wilayah perkotaan, pedesaan maupun pada daerah pendukung.

Pemerintah Daerah mengendalikan seluruh kegiatan pembangunan RTH kota dengan tidak memberikan ijin perubahan penggunaan RTH untuk kepentingan/peruntukan lainnya. Pemerintah Daerah wajib melakukan pengendalian secara ketat tentang pemberian dan pencabutan izin pembangunan RTH kota (Inmendagri No 14 tahun 1988).

Peraturan Menteri Pekerjaan Umum Nomor 5 Tahun 2008 tentang Pedoman Penyediaan dan Pemanfaatan Ruang Terbuka Hijau di Kawasan Perkotaan menyatakan bahwa penyediaan RTH terbagi atas 3, yaitu sebagai berikut:

(1) Penyediaan RTH berdasarkan luas wilayah;

(2) Penyediaan RTH berdasarkan jumlah penduduk; (3) Penyediaan RTH berdasarkan kebutuhan fungsi tertentu.

\section{METODE}

Jenis penelitian yang digunakan dalam penelitian ini yaitu jenis deskriptif kuantitatif. Penelitian ini dilakukan di kecamatan Biringkanayakota Makassar. Penelitian dilakukan pada bulan Februari sampai Maret. Subjek dalam penelitian ini adalah orang yang terlibat dalam proses kehidupan sehari-hari yang dialami yaitu perangkat pemerintahan yang berperan dalam penataan tata kota dan lahan. Teknik pengumpulan data yang digunakan dalam penelitian ini yaitu Teknik Dokumentasi, Teknik Wawancara, Teknik Observasi, dan Teknik Survei. Pada penelitian ini teknik analisis data yang digunakan yaitu: (a) Analisis deskriptif kondisi eksisting RTH, (b) Analisis deskriptif fungsi RTH, dan (c) Penilaian kategori bagus, sedang, dan rendah akan dihitung melalui kriteria dengan pendekatan ilmu arsitektur

\section{HASIL PEMBAHASAN}

Luas wilayah kecamatan Biringkanaya adalah 3163,81 Ha atau 27,04 \% dari luas keseluruhan kota Makassar dengan ketinggian $0-30$ m dari permukaan laut. Penggunaan lahan di Kecamatan Biringkanaya Kota Makassar pada umumnya dipadati oleh pemukiman dengan persentase 39,68\% dari luas Kecamtan Biringkanaya. Hasil penelitian mengenai luas RTH yang ada di kecamatan Biringkanaya berdasarkan masing-masing jenisnya dapat di lihat pada tabel I sebagai berikut 
UNM Environmental Journals, Vol. 2 No. 1 Desember 2018 hal. $18-23$

Tabel 3.1 Jenis RTH di Kecamatan Biringkanaya tahun 2018

\begin{tabular}{|l|l|l|l|}
\hline No & \multicolumn{1}{|c|}{ Jenis RTH } & \multicolumn{1}{c|}{ Luas Ha } & \multicolumn{1}{c|}{$\begin{array}{c}\text { Persentase } \\
\text { Terhadap Luas (\%) }\end{array}$} \\
\hline 1 & Hutan Kota & 75,98 & 10,45 \\
\hline 2 & Taman & 115,93 & 15,95 \\
\hline 3 & Lapangan & 215,49 & 29,64 \\
\hline 4 & Jalur Hijau & 8,86 & 1,22 \\
\hline 5 & Hutan Mangrove & 10,11 & 1,39 \\
\hline 6 & Sawah & 262,73 & 36,14 \\
\hline 7 & Pemakaman & 18,43 & 2,54 \\
\hline 8 & Fasum \& Fasos & 19,49 & 2,68 \\
\hline Jumlah & 727,019 & 100 \\
\hline
\end{tabular}

Sumber: Dinas Lingkungan Hidup Kota Makassar 2018

Berdasarkan Direktorat Jenderal Penataan Ruang (2006), RTH dibangun untuk memenuhi berbagai fungsi dasar yaitu fungsi ekologis, fungsi estetika, dan fungsi sosial- ekonomi. Dari penelitian ini didapatkan hasil pengamatan dan eksplorasi terhadap tiga fungsi RTH di kecamatan Biringkanaya yaitu eksplorasi fungsi ekologis yaitu masyarakat sebagai pengguna merasakan manfaat akan keberadaan RT sebagai pencipta iklim mikro. Jenis dan keragaman vegetasi, penentuan lokasi RTH dan penggunaan material yang alami sangat berpengaruh sebagai faktor penentu terciptanya iklim mikro pada RTH (Subair, N. and Haris, R., 2018).

Dari pengamatan hasil penelitian pada penjelasan tentang fungsi RTH di kecamatan Biringkanaya dalam hal ini Taman Ayam Daya, Hutan Mangrove Untia, dan Lapangan Golf Baddoka dapat dilihat pada tabel 3.2 berikut.

Tabel 3.2 Fungsi RTH di Kecamatan Biringkanaya

\begin{tabular}{|c|c|c|c|c|}
\hline \multirow[b]{2}{*}{ Fungsi } & \multirow[b]{2}{*}{ Standar } & \multicolumn{3}{|c|}{ Objek RTH Kecamatan Biringkanaya } \\
\hline & & $\begin{array}{c}\text { Taman } \\
\text { Ayam Daya } \\
(\%)\end{array}$ & $\begin{array}{c}\text { Hutan } \\
\text { Mangrove Untia } \\
(\%)\end{array}$ & $\begin{array}{c}\text { Lapangan Golf } \\
\text { Baddoka } \\
(\%)\end{array}$ \\
\hline \multirow{2}{*}{ Ekologis } & $\begin{array}{l}\text { RTH menjadi bagian dari } \\
\text { sistem sirkulasi udara (paru- } \\
\text { paru kota). }\end{array}$ & \multirow{2}{*}{50} & \multirow{2}{*}{100} & \multirow{2}{*}{100} \\
\hline & $\begin{array}{c}\text { Pengatur iklim mikro, } \\
\text { penyerapan air tanah. } \\
\text { Mencegah abrasi. }\end{array}$ & & & \\
\hline \multirow{2}{*}{ Estetika } & $\begin{array}{l}\text { Meningkatkan kenyamanan, } \\
\text { memperindah lingkungan. }\end{array}$ & \multirow{2}{*}{50} & \multirow{2}{*}{50} & \multirow{2}{*}{83,33} \\
\hline & $\begin{array}{l}\text { Pembentuk faktor keindahan } \\
\text { arsitektural }\end{array}$ & & & \\
\hline \multirow[t]{2}{*}{$\begin{array}{l}\text { Sosial- } \\
\text { Ekonomi }\end{array}$} & $\begin{array}{l}\text { Tempat rekreasi; wadah dan } \\
\text { objek pendidikan, penelitian, } \\
\text { dan pelatihan dalam } \\
\text { mempelajari alam. }\end{array}$ & \multirow[t]{2}{*}{50} & \multirow[t]{2}{*}{83,33} & \multirow[t]{2}{*}{50} \\
\hline & $\begin{array}{l}\text { Memberikan peluang ekonomi } \\
\text { terhadap masyarakat. }\end{array}$ & & & \\
\hline & Rata-rata & 50 & 77,78 & 77,78 \\
\hline
\end{tabular}


Berdasarkan dari rekapitulasi tabel 4.17 di atas, maka fungsi ekologis untuk Taman Ayam Daya yaitu $50 \%$ yang berarti kategori sedang, untuk Hutan Mangrove Untia dan Lapangan Golf Baddoka yaitu $100 \%$ yang berarti kategori bagus. Fungsi estetika untuk Taman Ayam Daya dan Hutan Mangrove Untia yaitu 50\% berarti kategori sedang, untuk Lapangan Golf Baddoka yaitu 83,33\% yang berarti kategori bagus. Fungsi sosial-ekonomi untuk Taman Ayam Daya dan Lapangan Golf Baddoka yaitu 50\% yang berarti kategori sedang, untuk Hutan Mangrove Untia yaitu 83,33\% berarti kategori bagus.

Hal ini menujukkan bahwa fungsi RTH di kecamatan Biringkanya masih belum memenuhi fungsi dasar RTH yang baik, perlunya peningkatan fungsi di Taman Ayam Daya, peningkatan fungsi estetika di Hutan Mangrove Untia, dan peningkatan fungsi sosial-ekonomi di Lapangan Golf Baddoka.

\section{KESIMPULAN}

Hasil penelitian ini menunjukkan bahwa rerata fungsi RTH di Taman Ayam Daya yaitu sebesar 50\% yang berarti kategori sedang, sedangkan Hutan Mangrove Untia dan Lapangan Golf Baddoka yaitu sebesar 77,78\% yang berarti kategori bagus. Hutan Mangrove Untia dan Lapangan Golf Baddoka memiliki persentase tertinggi yang berarti memenuhi fungsi di antara RTH di kecamatan Biringkanaya.

\section{Referensi}

Rasyid, R., Dirawan, G.D., Umar, R. and Pertiwi, N., 2017. Analisis Indikasi dan Pola Kemiskinan Masyarakat Di Kota Makassar Provinsi Sulawesi Selatan. UNM Environmental Journals, 1(1), pp.2832.

Badan Pusat Statistik. 2017. Makassar Dalam Angka Tahun 2017. Makassar.

Departemen Dalam Negeri. 1988. Instruksi Menteri Dalam Negeri No. 14 Tahun 1988 tentang Penataan Ruang Terbuka Hijau di Wilayah Perkotaan. Jakarta.

Direktorat Jenderal Penataan Ruang. 2006. RTH Sebagai Unsur Utama Tata Ruang Kota. Departemen Pekerjaan Umum. Jakarta.

Peraturan Menteri Pekerjaan Umum No: 05/PRT/M/2008 tentang Pedoman Penyediaan dan Pemanfaatan Ruang Terbuka Hijau di Kawasan Perkotaan.

Shirvani, H. 1985. The Urban Design Process. New York: Van Nostrand Reinhold Company.

Sembel, S., Malik, A. \& Moniaga, L. 2015. Peningkatan kualitas ruang terbuka hijau melalui pembangunan taman pkk di Kecamatan Kalawat. Media Matrasain. 12 (3): 54-61.

Subair, N. and Haris, R., 2018, August. Partisipasi Masyarakat Perkotaan Dalam Pengelolaan Ruang Terbuka Hijau Sebagai Pertanian Urban, Makassar, Indonesia (Studi kasus Kelurahan Bongaya, Kecamatan Tamalate). In Seminar Nasional Hasil Penelitian (SNP2M PNUP). 